\title{
Análise Teórica e Epistemológica de Jogos para o Ensino de Química Publicados em Periódicos Científicos
}

\section{Theoretical and Epistemological Analysis of Games for Teaching Chemistry Published in Scientific Journals}

\author{
Felipe Augusto de Mello Rezende \\ Márlon Herbert Flora Barbosa Soares

Nos últimos anos houve um aumento considerável no número de publicações envolvendo a aplicação de jogos para o ensino de Química. No entanto, tais publicações não vêm necessariamente acompanhadas de referenciais teóricos adequados, ou, quando utilizados, não se relacionam diretamente com questões de ensino e aprendizagem. Dessa forma, pretendemos analisar uma série de artigos científicos de diversas revistas, entre os anos 2000-2016, no sentido de desvelar a utilização de referenciais teóricos de ensino e aprendizagem e a partir desta análise, verificar como os jogos vêm sendo estruturados, tanto em relação aos referenciais adotados, quanto à preocupação com a aprendizagem dos alunos. Os resultados apontam para a necessidade de se discutir o papel do jogo enquanto metodologia de ensino e aprendizagem, pois a utilização de referenciais epistemológicos ainda é muito incipiente, sendo que poucos conceitos teóricos são explorados pelos pesquisadores. A grande maioria dos jogos utilizam os referenciais epistemológicos como metodologia de aprendizagem, pois tais concepções são elencadas com objetivo de confirmar os conceitos trabalhados nas aulas expositivas, o que não tem contribuído para a aprendizagem dos alunos.

Palavras-Chave: jogos em ensino de química; teorias de ensino e aprendizagem; periódicos científicos.

In recent years there has been a considerable increase in the number of publications involving the application of games for teaching Chemistry. However, such publications are not necessarily accompanied by adequate theoretical frameworks or, when used, are not directly related to teaching and learning issues. Thus, we intend to analyze a series of scientific articles from various journals between the years 2000 to 2016 in order to reveal the use of theoretical references of teaching and learning, and, from this analysis, to verify how games have been structured, in relation not only to the adopted references, but also to the students' learning. The results point to the need to discuss the role of gaming as a teaching and learning methodology, since the use of epistemological references is still very incipient, and few theoretical concepts are explored by the researchers. The vast 
majority of games use the epistemological references as a learning methodology, since such conceptions are listed with the purpose of confirming the concepts worked in the lectures, which has not contributed to the students' learning.

Keywords: games in chemistry teaching; teaching and learning theories; scientific journals.

\section{Pequeno Preâmbulo Sobre a História e definição dos jogos}

A história contemporânea dos jogos remete à Grécia e Roma antigas, cujos relatos indicam sua utilização em diversos âmbitos. Neste período, os soldados utilizavamnos como forma de preparação para as batalhas, desenvolvendo estratégias de ataque e defesa por meio de jogos de representação. Além dos soldados, as doceiras utilizavam para alfabetizar as crianças, guloseimas na forma de letras do alfabeto. No decorrer dos anos, filósofos como Aristóteles e Platão iniciaram as discussões acerca da necessidade de se aprender brincando, enfatizando a importância do jogo na prática pedagógica (Kishimoto, 2011a).

De acordo com Duflo (1999), a utilização dos jogos na formação do ser humano, é extremamente redundante e pouco evolutiva, pois durante muitos anos (aproximadamente do século IV ao século XVI), período denominado Cristianismo (por volta dos anos 380), era vedado a utilização de quaisquer tipos de jogos, pois a igreja católica considerava-os como atividades delituosas, associadas à prostituição e embriaguez. Somente a partir do século XVI, com o surgimento de novas ideias e concepções pedagógicas (período denominado Renascimento), o jogo é reabilitado e incorporado na formação dos nobres. Nesse período, Thomas Murner e Inácio de Loyola preconizaram a utilização de jogos de cartas para ensinar dialética à nobreza (Kishimoto, 2011b).

A grande eclosão do movimento iniciado na Grécia e Roma antigas ocorre no século XVIII, com a popularização dos jogos que antes se restringiam à nobreza. De acordo com Duflo (1999), esse período é considerado como o século do jogo, por demarcar o surgimento de escolas cujas metodologias de ensino pautavam-se em jogos. Embora existam relatos que remetam a utilização dos jogos a mais de dois mil anos, caminhou-se pouco acerca do objeto de estudo. Assim, observa-se atualmente uma grande dificuldade por parte dos docentes em utiliza-los como metodologia de ensino, isso se deve, provavelmente, ao desconhecimento acerca da sua estruturação e potencial pedagógico.

De acordo com Soares (2015) e Rezende (2017), no Brasil a dificuldade de compreensão do que vem a ser jogo, é evidenciada até mesmo nos dicionários, que consideram que os termos: jogo, brinquedo e brincadeira, possuem o mesmo significado. Ou seja, há no Brasil uma polissemia muito grande no que se refere ao vocábulo jogo. Estes termos são entendidos como sinônimos na língua portuguesa, entretanto, jogo, brinquedo e brincadeira, possuem significados distintos. 
No sistema educacional, há ainda mais dificuldade em definir termos como: jogo educativo, atividade lúdica e brinquedo. De acordo com Soares (2015), atividade lúdica corresponde às ações que geram um mínimo de prazer e divertimento, estando diretamente relacionada aos jogos, sendo que diferentemente dos jogos, não há existência de regras. Contudo, se o objeto apresentar um conjunto de regras (jogo), proporcionar diversão (função lúdica) e também servir para auxiliar a prática docente, buscando contribuir para o aprendizado dos alunos (função educativa), este, recebe o nome de jogo educativo/didático. Entretanto, para Kishimoto (2011b), se o objeto não apresentar nenhum objetivo pedagógico e servir apenas como método de descontração, ou seja, explorar somente a função lúdica será considerado um brinquedo.

As definições apresentadas acerca dos jogos na educação são importantes no sentido de compreender as funções que eles podem desempenhar. No entanto, temse identificado atividades com predominância da função educativa, cujos objetivos restringem-se à memorização de conceitos. Desta forma, Soares (2015) classifica os jogos em educativos e didáticos.

Os jogos educativos compreendem as atividades desenvolvidas para ensinar determinados conteúdos, no qual o pesquisador lança mão do jogo antes de abordar o conteúdo em questão, sendo-o neste sentido, uma ferramenta de ensino. Tais características convergem com as funções apresentadas por Kishimoto (2011b), que ressalta a importância do equilíbrio entre a diversão e a inserção dos conteúdos. Contudo, diferentemente do jogo educativo, os jogos didáticos englobam as atividades realizadas pós conteúdos, no qual o jogo é utilizado como forma de fixação dos conceitos elencados por outros métodos de ensino, havendo predominância da função educativa. Em um trabalho mais recente, Cleophas, Cavalcanti e Soares (2018) aprofundam-se na questão e nos dizem que todos os jogos são em alguma medida, educativos. No entanto, os jogos educativos utilizados em ambientes formais de ensino, como as salas de aula, são chamados de jogos educativos formalizados. Estes, por sua vez, podem ser pedagógicos, ou seja, abordam o conteúdo sem a necessidade de aulas prévias e funcionam como uma ferramenta de ensino e também podem ser didáticos, ou seja, são utilizados como reforço de algum conteúdo já ministrado.

A variedade de jogos didáticos/pedagógicos descritos na literatura, cujos objetivos pedagógicos variam de acordo com os referenciais adotados, leva-nos a questionar acerca do seu potencial educacional, enquanto ferramenta de ensino e aprendizagem. Neste sentido, o presente trabalho pretende fazer uma análise teórica-epistemológica dos jogos que vem sendo utilizados para o ensino de Química, nos principais periódicos de Ensino/Educação em Química no recorte de 2000-2016. Dessa forma, pretendemos desvelar a utilização de referenciais teóricos de ensino e aprendizagem e a partir desta análise, verificar como os jogos vêm sendo estruturados, tanto em relação aos referenciais adotados, quanto à possível preocupação com a aprendizagem dos alunos.

Neste trabalho, optamos por explorar Piaget e Vigotski, para tentar entender como se dá a construção dos jogos nestas concepções, bem como os possíveis elementos 
teóricos explorados, e se estes tem favorecido o aprendizado dos alunos a partir da proposta do trabalho, visto que a simples utilização de referenciais epistemológicos na escrita do trabalho não garante que estes tenham sido explorados na elaboração dos jogos. Para isso, se faz necessário compreender as concepções de jogos na perspectiva dos referidos pesquisadores.

\section{O Jogo na Concepção Piagetiana}

$\mathrm{Na}$ concepção Piagetiana, a inteligência compreende um equilíbrio entre a assimilação e a acomodação, correspondendo respectivamente à aquisição e compreensão de novas informações, ou seja, processo de significação das informações assimiladas. Para Piaget, o jogo é essencialmente assimilação, podendo também ocorrer acomodação, no entanto, há uma primazia da assimilação sobre a acomodação. Assim, a ludicidade acompanha o desenvolvimento da inteligência, sendo-a vinculada aos estágios de desenvolvimento (Piaget, 1978).

O jogo é compreendido como um fenômeno de pré-exercício, neste sentido, ele pode ser explicado pelo processo biológico pelo qual os órgãos se mantêm em funcionamento, ou seja, para desenvolver, os órgãos necessitam de alimento, sendo que conforme o processo se intensifica, as necessidades também se acentuam. Os jogos desempenham o mesmo papel, pois conforme as crianças se desenvolvem, eles se intensificam de acordo com sua capacidade de assimilação (Piaget, 1978).

Embora seja difícil precisar o momento em que se inicia a utilização dos jogos, Gross (1902) considera que o jogo tem início na primeira fase de desenvolvimento da criança, pois segundo filósofo o jogo é um pré-exercício dos instintos essenciais. Assim, a criança passa a repetir ações fora de seu contexto que remetem às estruturas essenciais de cada indivíduo. Um exemplo claro é a sucção do leite, considerado como um instinto presente na estrutura cognitiva, que posteriormente é exercitado fora do seu contexto, no qual a criança realiza-o distante das refeições, simplesmente pelo prazer de repetir a ação de mamar (Piaget, 1978).

O jogo é definido por Piaget (1978) como uma atividade autotélica e espontânea, marcada pelo prazer, cuja organização varia de acordo com o nível de desenvolvimento cognitivo, além de consistir em uma atividade que permite ao indivíduo libertar-se dos seus problemas, gerando certa satisfação momentânea. O caráter autotélico do jogo relaciona-se ao desinteresse pela atividade, encontrado nas primeiras fases de desenvolvimento, ou seja, é uma atividade que tem um fim em si mesmo, de acordo com Piaget (1978) "nos primeiros meses de vida, a criança olha por olhar, manipula por manipular” (p. 119), ou seja, desenvolve ações sem nenhuma finalidade específica, assim como o jogo, que a criança presente no estágio sensório-motor realiza mecanicamente. No entanto, esta característica autotélica vai desaparecendo de acordo com o desenvolvimento da criança, pois ela passa a se envolver no jogo, de forma a realizá-lo para atingir determinados objetivos.

A espontaneidade presente nos jogos possibilita que os indivíduos possam 
realizá-los sem nenhuma obrigatoriedade, brincam simplesmente para satisfazer uma necessidade biológica, para se divertir, e quando há imposição externa, que obrigue a criança a participar da atividade, ela deixa de ser um jogo. No cenário educativo, uma das principais dificuldades encontradas por parte dos professores, refere-se à elaboração de um jogo que desperte o prazer dos alunos, de forma que não seja necessário obrigálos a participar da atividade, o que o desconfiguraria de um jogo.

A diversão é uma das principais características do jogo, pois ele é considerado por Piaget (2014) como uma atividade que persegue o prazer, diferentemente do trabalho, que muitas das vezes é subordinado a situações de adaptação à realidade, que nem sempre produzem sentimentos prazerosos. As características descritas por Piaget $(1978,2014)$ culminam na utilização do jogo como uma rota de fuga da realidade, ou seja, se no trabalho muitas das vezes o indivíduo não encontra elementos suficientes que o motive e torne suas ações prazerosas, ele busca no jogo uma maneira de satisfazer suas necessidades, podendo ignorar toda a realidade subjetiva, libertando-o momentaneamente dos problemas e conflitos cotidianos.

A compreensão da gênese do jogo possibilitou a Piaget dedicar-se ao seu desenvolvimento ulterior, de forma a compreender seu funcionamento nos diferentes níveis do pensamento verbal e intuitivo, para isso ele cria três categorias de classificação do jogo, sendo-as: jogos de exercício, jogos simbólicos e os jogos de regras. Contudo, importante ressaltar que Piaget considera não apenas as questões biológicas, mas também questões sociais, que assim como os estímulos biológicos, devem ser levadas em consideração na escolha dos conteúdos presentes nos jogos, pois este deve se adequar tanto à idade das crianças, quanto ao contexto social que elas estão inseridas (Piaget, 1978).

Os jogos de exercício são caracterizados simplesmente pelo prazer funcional, cujo indivíduo realiza-o por mero divertimento, sendo desprovido da necessidade e de aprendizagem. Estes jogos são os primeiros a aparecerem nas crianças, não requerem necessidade de pensamento, pois as ações não modificam as estruturas cognitivas (Piaget, 1978). Piaget (2014) cita três das principais características dos jogos de exercício: vocalize, repetição com finalidade lúdica e a estereotipação. A vocalize consiste na emissão de diferentes sons pela criança, que geram um mínimo de prazer. Estes tipos de jogos de voz, não têm nenhum objetivo específico como chamar ou exprimir sentimentos, são realizados simplesmente pelo divertimento. A repetição com finalidade lúdica consiste na reprodução de ações que em algum momento foi realizada e gerou prazer, tais como: balançar, esfregar ou deslocar objetos. A estereotipação citada por Piaget é uma das últimas características que aparecem nos jogos de exercício, e consiste em transformar uma atividade motora como, por exemplo, tomar banho, em um jogo que lhe proporcione prazer.

[...] uma das minhas filhas, entrando na banheira, esteve a ponto de perder o equilíbrio, escorregou, largou a banheira sobre a qual sua mão se apoiava, bateu na água e, procurando manter seu equilíbrio, passou a mão sobre seus cabelos, depois limpou as 
gotas d'água do seu rosto e, finalmente, retomou o equilíbrio. Logo que ela reencontrou o equilíbrio, ela deu boas risadas e recomeçou o mesmo ritual. Nos dias seguintes, ela não podia entrar na banheira, sem reproduzir a mesma cena (Piaget, 2014, p. 316).

A segunda categoria descrita por Piaget, dos jogos simbólicos, compreende as ações que implicam representações de objetos ausentes, no qual a criança associa suas brincadeiras com objetos ou fatos recorrentes em seu cotidiano. $\mathrm{O}$ simbolismo presente em tais jogos consiste em atribuir vida e/ou função a objetos corriqueiros, como por exemplo, a criança utilizar um cabo de vassoura como sendo seu cavalo na brincadeira. Para realização dos jogos simbólicos, é necessário que a criança tenha situações assimiladas em sua estrutura cognitiva, pois seus jogos consistirão nas representações dos fatos vivenciados, que ocorrerão de acordo com seu imaginário e seus interesses. O simbolismo propicia a imitação, que embora não transforme a estrutura cognitiva, começa a desenvolver nas crianças o sentido da construção e colaboração, pois mesmo que a imitação seja predominante, cada indivíduo terá seu papel no jogo simbólico (Piaget, 1978).

Além da imitação e de sua capacidade de reproduzir cenas cotidianas, Piaget (2014) ressalta no jogo simbólico, a possibilidade de compensação e aceitação. Através do simbolismo, pode-se além de imitar e reproduzir o real, transformá-lo, no sentido de realizar compensações. $\mathrm{O}$ autor cita como exemplo, uma criança que ao encontrar um cão na rua, sente bastante pavor do animal, demonstrando pouca coragem, no entanto, ao chegar a sua casa, a criança organiza um jogo no qual ela recebe o cão em seu jardim com bastante coragem, compensando a atitude não demonstrada no momento em que se deparou com o animal na rua. Outra característica do simbolismo é a aceitação, que segundo Piaget (2014) também poderia ser chamado de jogo de terminação, pois consiste em uma forma de resolver um conflito que por algum motivo não foi completamente aceito.

Muitas vezes, na realidade, uma situação não foi aceita completamente, não foi assimilada afetivamente, por motivos de amor próprio ou outras razões quaisquer, e então essas situações, não aceitas na realidade, reaparecem no jogo, até a aceitação completa, até a liquidação do conflito (Piaget, 2014, p. 319).

Os jogos de regras supõem necessariamente relações sociais e interindividuais entre os participantes. Nesta etapa a criança começa a compreender e se adaptar à vida em sociedade, sendo que as regras impostas pelos grupos ressaltam a existência de limites, que devem ser respeitados para o bom andamento das ações. A partir dos jogos de regras, os participantes conseguem assimilar informações nas suas estruturas cognitivas, e por meio das situações vivenciadas, podem até mesmo acomodar determinados conceitos (Piaget, 1978). Embora os jogos de regras tenham início a partir dos três anos de idade (Figura 1), através da imitação dos jogos de regras realizados pelos adultos, ele constituise em jogo organizado somente a partir dos sete anos. 


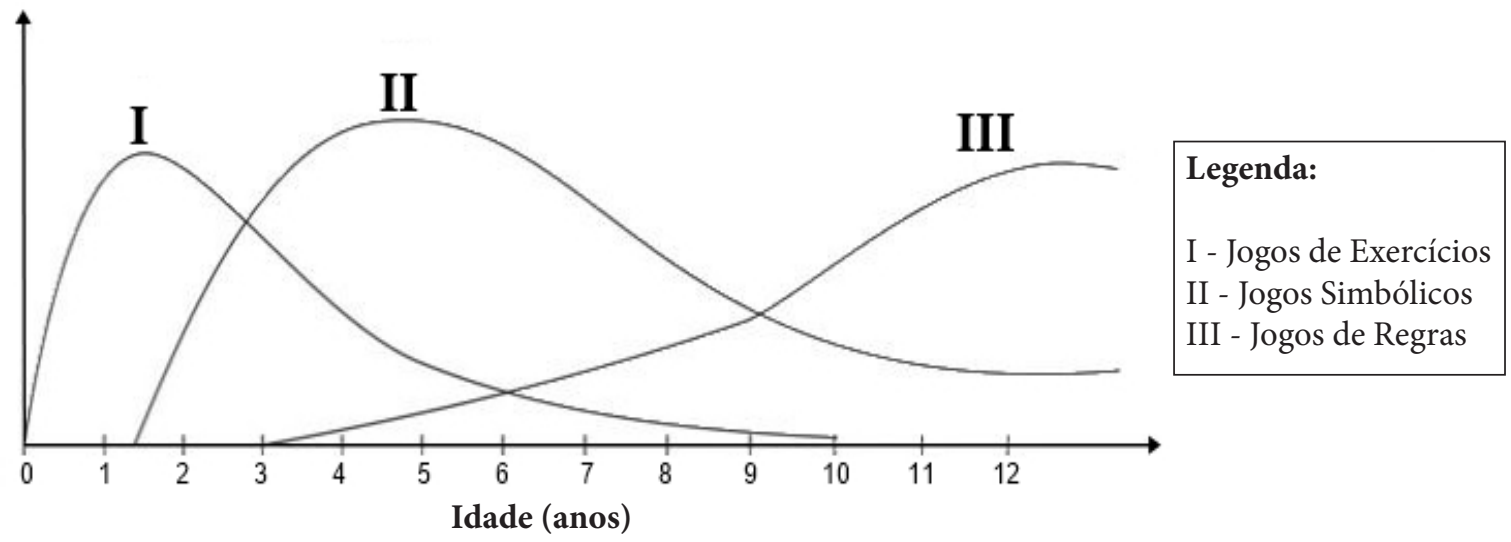

Figura 1. Evolução dos diferentes tipos de jogos de acordo com a idade

Fonte: Piaget, 2014.

Através da acentuação da curva dos jogos de regras, percebemos que eles vão se organizando e complexificando até a idade adulta, período que a maioria ou quase totalidade dos jogos, constitui-se em regras. Desta forma, percebe-se que os diferentes tipos de jogos variam de acordo com os níveis cognitivos das crianças, que vão se desenvolvendo no decorrer de sua vida, sendo que em um mesmo período/estágio podemos encontrar diferentes tipos de jogos, pois não necessariamente o início de um culmina no fim do outro. Importante destacar que pesquisas como a de Ferreira (2016), vêm identificando que a curva proposta por Piaget (2014) tem sido modificada com o passar dos anos, pois o pesquisador observou em seu trabalho que os jogos de exercício não cessam em determinado período, obviamente sua frequência diminui, mas não se finda. Outro aspecto refere-se ao aparecimento dos demais jogos (simbólico e de regras), que podem ocorrer antes ou depois do que Piaget propõe, devido aos estímulos que atualmente as crianças recebem.

Assim como os diferentes tipos de jogos, os níveis de assimilação variam de acordo com a idade das crianças, pois o desenvolvimento na perspectiva Piagetiana não acontece de forma linear, mas através de saltos e rupturas. Neste sentido, Piaget propõe três formas de equilibração (interação): INTRA, INTER e TRANS. A equilibração INTRA, decorre da interação entre os esquemas que o sujeito possui e os objetos a assimilar. Desta forma, na medida em que as novas informações são apresentadas, o sujeito encontra-se na obrigação de assimilar aos esquemas existentes (Aguiar Jr, 1999).

A segunda equilibração é a INTER, consiste na busca de equilíbrio entre os esquemas de assimilação que o sujeito possui, havendo uma relação de associação, no sentido de promover a complexidade da informação, de forma a relacioná-la com outras em busca de acomodação do conceito (Aguiar Jr, 1999). A terceira forma de equilibração, a TRANS, consiste, além da associação com outros esquemas, na hierarquização das informações, promovendo uma reflexão em nível formal, crítico. O conceito já acomodado agora pode ser usado e associado a outros, em esquemas que a princípio não apresentavam relação direta com o conceito, mas que fazem parte de um todo do 
intelecto (Aguiar Jr, 1999).

\section{O Jogo na Concepção Vigotskiana}

$\mathrm{Na}$ concepção histórico cultural a brincadeira realizada pelo ser humano, tem natureza social, no qual aprende-se a brincar por meio da inserção na cultura. Assim, diferentemente das concepções naturalizantes do jogo que marginalizam sua origem histórica, ele é compreendido como reflexo do seu tempo, de sua época, ou seja, uma conquista histórica repassada às crianças. Para Messeder Neto (2016), "O jogo nasce da inserção da criança no mundo e a apropriação cultural, o modo que se brinca e o conteúdo da brincadeira dependem dessa inserção da criança no mundo do adulto" (p. 146).

A ontogênese do jogo só poderia ser explicada a partir de uma perspectiva marxista, que considera sua origem só pode se dar a partir do trabalho, como forma de auxiliar em sua realização. Elkonin (2009) citado em Messeder Neto (2016) faz uma suposição do momento em que os jogos surgiram. De acordo com autor, os primeiros relatos de jogos estão relacionados ao planejamento de caçadas, visto o insucesso obtido nas anteriores. Desta forma, ao regressar de uma caçada infrutífera, os participantes reconstituem a mesma, de forma a verificar o que havia ocorrido de errado, para assim planejar ações que pudessem garantir o sucesso nas caçadas posteriores. Outra possibilidade apontada pelo filósofo seria o regresso dos caçadores com a presa, sendo que eles reproduziriam por meio de um jogo de representação as ações e comportamentos de cada membro, que teriam levado à captura do animal. Embora a ontogênese dos jogos remeta ao trabalho, não podemos explicar todos os jogos que temos atualmente pelo trabalho, pois a partir do momento que os jogos são criados, eles ganham certa independência e adquirem desenvolvimento próprio (Messeder Neto, 2016).

De acordo com Vigotski (2007) deve-se considerar as necessidades e inclinações da criança pela brincadeira, pois os motivos pelos quais ela joga, mudam de acordo com seu desenvolvimento. Assim, para o autor, "[...] qualquer deslocamento, qualquer passagem de um estágio etário para outro relaciona-se à mudança brusca dos motivos e dos impulsos para a atividade” (p. 24). As primeiras formas de jogo são encontradas na primeira infância, que compreende o período do nascimento até os três ou quatro anos de idade, período em que surgem os jogos protagonizados, pelo fato da criança brincar de imitar o que o adulto faz, devido a necessidade de se inserir no meio social (Vigotski, 2007).

O surgimento do jogo protagonizado ocorrerá, portanto, em condições nas quais a criança não pode se inserir na realidade do adulto. Ou seja, com as novas objetivações que foram deixando o mundo mais complexo, foi ficando cada vez mais difícil o acesso imediato à realidade social das pessoas maiores (Messeder Neto, 2016, p. 149).

No entanto, Messeder Neto faz uma importante ressalva em relação à existência do jogo protagonizado, que de acordo com o pesquisador nem sempre ocorreu, visto suas raízes históricas. Elkonin (2009) citado em Messeder Neto (2016) busca explicação 
para a assertiva em estudos etnográficos realizados com tribos primitivas da Rússia, no qual percebia-se que desde muito cedo as crianças adentravam-se na vida adulta, não sendo renegado nada a elas, e desta forma não havia sentido as crianças imitarem as atividades realizadas pelos adultos, ou seja, não havia jogo protagonizado. Outro exemplo elucidado por Elkonin refere-se a uma tribo denominada lopários, no qual os jogos protagonizados são bastante raros e quando aparecem, são formas de imitar situações que as crianças não têm acesso imediato, como por exemplo, a cerimônia de noivado.

Os jogos protagonizados ou de faz de conta, diferentemente de outras concepções de jogos, não se constituem como uma fuga da realidade da criança, mas como uma forma de adentrar-se ao mundo dos adultos ou até mesmo brincar daquilo que não lhe é imediatamente acessível. Para Elkonin (2009) o jogo é definido como uma atividade de reconstrução das relações sociais, sem fins utilitários diretos. A definição apresentada está diretamente relacionada com a ideia de jogo protagonizado, no qual a criança pode, por exemplo, interpretar um médico atendendo um paciente, estabelecendo assim uma relação social, que se difere do real pelo fato de que na brincadeira não há finalidade de cura (Messeder Neto, 2016).

Os jogos de representação (protagonizados) estão presentes no decorrer da vida do ser humano, no entanto, conforme os estágios vão se intensificando, outros tipos de jogos ganham ênfase, como é o caso da idade pré-escolar, no qual percebese o início da inserção dos jogos de regras explícitas, cuja competição se intensifica. De acordo com Vigotski (2008), a regra é uma das características da brincadeira, e ela normalmente aparece até mesmo nos jogos de representação, onde podemos observar de forma implícita a presença de regras de comportamento, e ganham ênfase nos jogos de competição, que há explicitação das regras antes de se iniciar as atividades (jogos de dama, xadrez, futebol). Da mesma forma, nos jogos de regras explícitas podemos encontrar a presença das situações imaginárias.

Parece-me que sempre que há uma situação imaginária na brincadeira, há regra. Não são regras formuladas previamente e que mudam ao longo da brincadeira, mas regras que decorrem da situação imaginária. Por isso, é simplesmente impossível supor que a criança pode se comportar numa situação imaginária sem regras, assim como se comporta numa situação real. Se a criança faz o papel da mãe, então ela tem diante de si as regras do comportamento da mãe. O papel que a criança interpreta e a sua relação com o objeto, caso este tenha seu significado modificado, sempre decorrem das regras, ou seja, a situação imaginária, em si mesma, sempre contém regras (Vigotski, 2008, p. 28).

As regras postas nos jogos traduzem as relações sociais de boa conduta ou não, presentes em nosso cotidiano, pois existem casos em que as relações sociais podem levar a caminhos desagradáveis, como por exemplo, o jogo denominado banco imobiliário, que carrega uma série de conceitos relacionados ao dinheiro, cujo objetivo seria levar os outros oponentes à falência, explicitando sua forte relação capitalista. Assim “[...] todo 
jogo representa, em maior ou menor grau, as relações sociais postas no seu tempo ou de um tempo passado que foi transmitido para as novas gerações, ainda que implicitamente" (Messeder Neto, 2016, p. 151).

Análogo às regras, destacamos a visão de Vigotski (2008) quanto à ludicidade (prazer, divertimento) presente nos jogos. Diferentemente das concepções naturalizantes que consideram que as crianças jogam por ser uma atividade extremamente prazerosa e divertida, Vigotski não considera o prazer como uma característica intrínseca e sempre presente nos jogos, pois existem atividades que podem causar mais satisfação nas crianças do que o próprio jogo, e também o fato dos jogos de competição ter um único vencedor, podendo gerar desprazer nos demais participantes. Outro aspecto destacado por Messeder Neto (2016) em relação à concepção Vigotskiana acerca do jogo está relacionado com os objetivos finais determinados pela criança quanto à atividade, que segundo epistemólogo determina a relação afetiva da criança com o jogo. No entanto, Messeder Neto (2016) compreende a importância que o objetivo final possui na relação afetiva da criança com o jogo, mas considera que ele não deve prevalecer sobre o processo.

A criança, ao perder o jogo, ficará frustrada, mas essa frustração não deve ser maior do que o prazer posto pelo ato lúdico. Esse prazer do processo precisa vigorar sobre o produto para que a criança volte a jogar em outro momento (Messeder Neto, 2016, p. $153)$.

As características descritas, segundo Vigotski (2008) faz com que a criança aprenda por meio dos jogos a agir nas linhas de menor e maior resistência, pois nas brincadeiras ela encontrará os dois extremos, dos quais poderá fazer o que mais deseja, mas também haverá situações em que deverá recusar aquilo que mais lhe chama a atenção, pelo fato de ter que se submeter às regras. Assim, a brincadeira é compreendida por Vigotski como fonte de desenvolvimento, e cria a zona de desenvolvimento iminente na criança, pois suas ações presentes nas brincadeiras estarão sempre acima da sua média de idade, acima do seu comportamento cotidiano.

\section{Procedimentos Metodológicos}

A Química como uma Ciência exata, utiliza-se muito de métodos quantitativos, contudo, a partir da década de 70, tem-se identificado uma crescente utilização de métodos qualitativos nos países da América Latina. A pesquisa qualitativa tem suas raízes nas práticas desenvolvidas pelos antropólogos e sociólogos que estudavam a vida em comunidade, tendo seu surgimento como um acontecimento natural, ligado à necessidade de se compreender e analisar os acontecimentos que emergiam da sociedade, análogo aos métodos de quantificação utilizados até então (Triviños, 1987).

De acordo com Gerhaldt e Silveira (2009), a principal característica dos métodos qualitativos está relacionada com a busca de explicação do por que das coisas. Para isso, segundo Flick (2009), a pesquisa qualitativa parte da ideia da estruturação social do objeto de estudo, cujo interesse está pautado tanto na compreensão dos sujeitos, quanto em seus hábitos rotineiros e saberes relacionados ao que se pretende analisar. Assim, 
procura-se entender os significados dos dados de forma subjetiva e particular, de acordo com o contexto no qual estão inseridos, ou seja, compreender os processos que formam os fenômenos investigados.

A inserção da pesquisa qualitativa na educação deve-se principalmente à necessidade de se interpretar e intervir nos problemas provenientes do âmbito escolar, que até então eram apenas quantificados, o que basicamente não contribuía em nada para melhoria da qualidade do ensino (Triviños, 1987). Desta forma, a pesquisa caracterizase como qualitativa, por procurar compreender quais elementos constitutivos destas teorias relacionadas aos processos de ensino e aprendizagem são explorados nos artigos que utilizam jogos para o ensino de Química, e como tais aspectos contribuem ou poderiam contribuir para a aprendizagem dos alunos.

Para análise dos dados provenientes dos artigos, utilizou-se o método denominado análise documental, que consiste em uma técnica de análise de dados qualitativos, complementar às informações obtidas por outras técnicas. As análises documentais buscam interpretar as informações contidas nos documentos, orientadas por questões ou hipóteses do objeto de estudo, sendo que os documentos constituem uma fonte importante de evidências que fundamentam as asserções do pesquisador (Lüdke, \& André, 1986).

A análise documental inicia-se com a escolha de oito periódicos (Figura 2), cuja seleção dos artigos que utilizam jogos para o ensino de Química se deu no período de 2000-2016, justificando-se pela pesquisa realizada por Garcez (2014), que identificou poucos trabalhos sobre jogos até os anos 2000. Importante destacar que o recorte se deu até o ano de 2016 pelo fato de ser o período no qual os dados foram coletados, quando consideramos que a pesquisa teve seu encerramento no ano de 2017. A escolha dos periódicos levou em consideração sua importância na Educação/Ensino de Química, pois além de apresentarem qualis relevante $(\mathrm{A}-\mathrm{B})$, são os periódicos que mais publicam acerca do objeto de estudo (lúdico).

\begin{tabular}{|l|c|c|}
\hline Periódicos & $\begin{array}{c}\text { Qualis em } \\
\text { Educação/Ensino }\end{array}$ & $\begin{array}{c}\text { Quantidade } \\
\text { de Artigos }\end{array}$ \\
\hline Alexandria & B2/A2 & - \\
\hline Ciência \& Educação & $\mathrm{A} 1 / \mathrm{A} 1$ & - \\
\hline Química Nova (QN) & $\mathrm{A} 2 / \mathrm{B} 3$ & 1 \\
\hline Química Nova na Escola (QNEsc) & $\mathrm{B} 1 / \mathrm{B} 1$ & 14 \\
\hline Revista Brasileira de Pesquisa em Educação em Ciências (RBPEC) & $\mathrm{A} 2 / \mathrm{A} 2$ & 1 \\
\hline Revista Brasileira de Ensino de Química (ReBEQ) & $\mathrm{B} 5 / \mathrm{B} 1$ & 6 \\
\hline Revista Electrónica de Enseñanza de las Ciencias (REEC) & $\mathrm{A} 2 / \mathrm{A} 2$ & 2 \\
\hline Total & & 24 \\
\hline
\end{tabular}

Figura 2. Periódicos analisados na pesquisa

Fonte: Autores.

Após a seleção dos artigos criou-se duas categorias a priore (Jogo na Concepção 
Piagetiana e Jogo na Concepção Vigotskiana), para classificar os artigos de acordo com os referenciais identificados, e posteriormente analisar quais aspectos teóricos dos referidos autores eram explorados nos jogos. A categoria denominada Jogo na Concepção Piagetiana, engloba os artigos que utilizam as concepções de jogos relacionadas com as propostas por Jean Piaget, assim como a categoria que engloba os artigos relacionados às concepções de Lev Vigotski. Além das categorias descritas, a análise dos artigos evidenciou a necessidade da criação de uma terceira categoria, a posteriore, que abrangesse os artigos que não utilizam nenhum referencial epistemológico, sendo-a denominada Ausência de Referencial Epistemológico.

\section{Que os Jogos Comecem}

A partir da compreensão das concepções de jogos em Piaget e Vigotski, categorizouse os artigos de acordo com os referenciais utilizados ou ausência deles (Figura 3), e posteriormente discutiu-se os resultados obtidos em cada uma das categorias.

\begin{tabular}{|l|c|}
\hline Categorias & Quantidade de Artigos \\
\hline Ausência de Referencial Epistemológico & 4 \\
\hline Jogo na Concepção Piagetiana & 13 \\
\hline Jogo na Concepção Vigotskiana & 7 \\
\hline Total & 24 \\
\hline
\end{tabular}

Figura 3. Quantidade de artigos presentes em cada categoria.

Fonte: Autores.

\section{Jogando com Piaget}

Dentre os vinte e quatro artigos analisados, percebeu-se uma predominância do referencial Piagetiano, que compreende mais da metade dos trabalhos analisados. A Figura 4 apresenta os artigos elencados na categoria denominada Jogo na Concepção Piagetiana.

\begin{tabular}{|l|l|c|}
\hline Autor(es) & Título do trabalho & Ano \\
\hline Benedetti Filho et al. & $\begin{array}{l}\text { Palavras Cruzadas como Recurso Didático no Ensino de } \\
\text { Teoria Atômica }\end{array}$ & 2009 \\
\hline Castro, Dionízio, \& Silva & $\begin{array}{l}\text { Na Trilha dos Elementos Químicos: o Ensino de Química } \\
\text { através de uma atividade lúdica }\end{array}$ & 2015 \\
\hline Cavalcanti, \& Soares & $\begin{array}{l}\text { O uso do jogo de roles (roleplaying game) como estratégia de } \\
\text { discussão e avaliação do conhecimento químico }\end{array}$ & 2009 \\
\hline Ferreira, \& Nascimento & $\begin{array}{l}\text { Utilização do jogo de tabuleiro - ludo - no processo de } \\
\text { avaliação da aprendizagem de alunos surdos }\end{array}$ & 2014 \\
\hline
\end{tabular}

Figura 4. Artigos presentes na categoria Jogo na Concepção Piagetiana (continua)

Fonte: Autores. 


\begin{tabular}{|c|c|c|}
\hline Autor(es) & Título do trabalho & Ano \\
\hline Giacomini et al. & $\begin{array}{l}\text { Jogo Educativo sobre a Tabela Periódica aplicado no Ensino } \\
\text { de Química }\end{array}$ & 2006 \\
\hline Oliveira, \& Soares & $\begin{array}{l}\text { Júri Químico: Uma Atividade Lúdica para Discutir Conceitos } \\
\text { Químicos }\end{array}$ & 2005 \\
\hline Passos, \& Ribeiro & $\begin{array}{l}\text { Quest Química: um jogo como ferramenta na abordagem e } \\
\text { aprimoramento do conhecimento químico }\end{array}$ & 2012 \\
\hline Rodríguez & $\begin{array}{l}\text { Competencias comunicativas, aprendizaje y enseñanza de las } \\
\text { Ciencias Naturales: un enfoque lúdico }\end{array}$ & 2007 \\
\hline Roque & Química por meio do teatro & 2007 \\
\hline Santos et al. & $\begin{array}{l}\text { Aplicação de um Jogo Didático (Ludo) Explorando o } \\
\text { Conteúdo da Tabela Periódica no Ensino Médio }\end{array}$ & 2012 \\
\hline $\begin{array}{l}\text { Saturnino, Luduvico, \& } \\
\text { Santos }\end{array}$ & Pôquer dos Elementos dos Blocos $s$ e $p$ & 2013 \\
\hline Tasca, Tubino \& Simoni & $\begin{array}{l}\text { Dois jogos que auxiliam no entendimento da Tabela } \\
\text { Periódica }\end{array}$ & 2007 \\
\hline Vaz, \& Soares & $\begin{array}{l}\text { O ensino de Química para adolescentes em conflito com a } \\
\text { lei: possibilidades e desafios }\end{array}$ & 2008 \\
\hline
\end{tabular}

Figura 4. Artigos presentes na categoria Jogo na Concepção Piagetiana (continuação)

Fonte: Autores.

A análise dos jogos de acordo com a concepção Piagetiana, permitiu-nos verificar que todos os jogos descritos nos artigos são jogos de regras, sejam elas explícitas ou implícitas. As regras podem ter sido utilizadas pela idade dos participantes (Como a maioria dos jogos foram aplicados no Ensino Médio, acreditamos que os alunos tenham entre 14-17 anos de idade) que aflora a disputa/competição, e/ou para impor limites, e "garantir" o bom andamento da atividade. Análogo às regras, dois artigos utilizaram a representação para elaboração das propostas lúdicas, combinando características de dois tipos de jogos descritos por Piaget (1978), jogos de regras e os jogos simbólicos. Estes aspectos são encontrados nos artigos de Oliveira e Soares (2005) que propõem um júri simulado para discutir conceitos Químicos, e o de Roque (2007) que utiliza o teatro como ferramenta de ensino.

O professor/juiz apresenta o caso e passa a fala aos alunos/advogados escolhidos pelo grupo de cada fábrica, para que façam suas considerações iniciais. O próximo passo é a apresentação das provas de acusação e defesa construídas anteriormente nas reuniões de grupo nas quais os conceitos químicos foram trabalhados. Essa parte é apresentada por profissionais designados por cada grupo, para a explicação e discussão das provas. Esses profissionais são personificados pelos próprios alunos. Na experiência realizada, cada grupo apresentou quatro profissionais, sendo eles químicos, médicos, dentistas e engenheiros. Um detalhe importante a salientar é que os alunos se vestiram a caráter (Oliveira, \& Soares, 2005, p. 20).

[...] os jogos teatrais seguem um esquema que deve ser bem compreendido pelo aluno. 
Inicialmente, faz-se uma introdução ao exercício e indica-se o ponto de concentração ou foco. Esta é, na realidade, a ideia que deve ser trabalhada e transmitida para a platéia durante a improvisação. Em seguida, são dadas as instruções necessárias para a improvisação e, às vezes, um exemplo. Após as explicações, é dado um tempo de poucos minutos para que os grupos idealizem suas improvisações. E, por fim, as apresentações são realizadas (Roque, 2007, p. 28).

Assim como a predominância das regras, identificou-se dentro da categoria que quase a totalidade dos jogos exploram apenas o conceito da assimilação e embora alguns artigos até mencionem a acomodação, suas propostas ficam apenas no nível da assimilação, com exceção de um dos artigos, que atinge a acomodação (Figura 5).

\begin{tabular}{|l|l|l|l|}
\hline $\begin{array}{l}\text { Apenas } \\
\text { Assimilação }\end{array}$ & $\begin{array}{l}\text { Assimilação e busca pela } \\
\text { Acomodação }\end{array}$ & $\begin{array}{l}\text { Assimilação e atinge a } \\
\text { Acomodação }\end{array}$ & Total \\
\hline 10 artigos & 2 artigos & 1 artigo & 13 artigos \\
\hline
\end{tabular}

Figura 5. Níveis que os artigos atingem dentro da Epistemologia Piagetiana

Fonte: Autores.

Os jogos têm sido utilizados para confirmar os conteúdos trabalhados nas aulas expositivas e/ou verificar se os alunos assimilaram as informações trabalhadas pelo referido método. Para desenvolver tais propostas, os pesquisadores normalmente aplicam questionários estruturados como forma de verificação dos conceitos presentes nas estruturas cognitivas dos alunos, e a partir de então propõem aulas expositivas para suprir as lacunas identificadas, e posteriormente o jogo é utilizado para constatar se houve ou não assimilação.

[...] fez-se um levantamento de conteúdos estudados por meio de análise de registros nos cadernos e nas conversas com os alunos e, em seguida, uma revisão de conceitos básicos de química orgânica - os alunos não sabiam distinguir, por exemplo, cadeias carbônicas saturada e insaturada, normal e ramificada, homogênea e heterogênea - e de hidrocarbonetos; os conceitos, as regras de nomenclatura e as aplicações das funções orgânicas oxigenadas foram trabalhados de forma tradicional; utilizou-se o jogo ludo, após resolução de exercícios, como instrumento de avaliação.

O jogo, portanto, não teve caráter apenas avaliativo, mas também favoreceu o processo de ensino-aprendizagem ao mesmo tempo em que possibilitava aos alunos voltar e discutir conceitos estudados, algo que não é possível numa prova escrita (Ferreira, \& Nascimento, 2014, p. 33).

Os fragmentos extraídos do artigo de Ferreira e Nascimento (2014) nos levam ao questionamento em relação à forma com que a assimilação é explorada, pois o primeiro parágrafo da citação deixa subentendido que o jogo seria aplicado para analisar se os conceitos trabalhados na aula expositiva (regras de nomenclatura e funções orgânicas) teriam sido assimilados pelos alunos, confirmando o que inferimos anteriormente. No entanto, o segundo parágrafo ressalta o jogo como uma possibilidade de novas 
assimilações. Então surge o questionamento se os autores utilizaram o jogo como método de verificação do que já teria sido assimilado pelos alunos ou como uma proposta que possibilitasse novas assimilações.

Ao analisarmos referenciais do jogo como Soares (2015) e Kishimoto (2011a,b), percebemos que eles discutem sobre a aprendizagem pós jogo, que para eles, apresenta mais significado para o estudante. Como normalmente os alunos estão acostumados com um sistema mecânico de memorização das informações, quando lhes é apresentado novos conceitos por meio de atividades lúdicas (que tem como principal característica a diversão), eles assimilam as informações e se interessam pela atividade, ou seja, o jogo na maioria das vezes culmina em assimilação, desta forma, mesmo que os autores tenham utilizado o jogo como forma de verificação do que os alunos assimilaram na aula expositiva, ele também propiciou novas assimilações.

De acordo com Piaget (1978), o jogo desenvolvido por Ferreira e Nascimento (2014) culmina em equilibrações do tipo INTRA, pelo fato de decorrerem da interação entre os esquemas que o sujeito possui e os objetos a assimilar. Esta equilibração tem como principal obstáculo a dificuldade de coordenação entre os esquemas, observada no fragmento extraído do artigo de Passos e Ribeiro (2012), que será discutido posteriormente.

Um aluno afirmou não gostar de química, entretanto, sua justificativa se contrapôs à pergunta seguinte do questionário. A segunda pergunta foi "Já utilizou conhecimentos químicos no cotidiano?" Para essa pergunta, o aluno que havia respondido que não se identificava com a química, disse que já utilizou conhecimentos químicos no cotidiano (Passos, \& Ribeiro, 2012, p. 56-57).

Ao analisar os artigos elencados na categoria em discussão, percebeu-se que quando os autores conhecem os referenciais que estão embasando seus jogos, ou seja, utilizam os referenciais de forma explícita (fazendo menção à Piaget ou à sua teoria), normalmente há utilização de outros conceitos relacionados à epistemologia Piagetiana, além da assimilação (visto que os três artigos descritos na Figura 5 que exploram a acomodação, utilizam o referencial Piagetiano explicitamente), mesmo que ao término da atividade o jogo culmine apenas em assimilação.

$\mathrm{O}$ artigo de Passos e Ribeiro (2012) traz uma proposta de jogo com intuito de buscar uma equilibração em termos de aprendizagem, sendo que na epistemologia Piagetiana, poderíamos dizer que a proposta tem como objetivo a busca pela acomodação dos conceitos Químicos. No entanto, ao analisarmos os resultados, percebemos que embora o jogo tenha objetivado a acomodação, ele ficou apenas no nível da assimilação, pelo fato dos alunos serem "formados" em um sistema de memorização, que culminou na não assimilação dos conceitos trabalhados pré-jogo, e consequentemente o jogo acabou suprindo as lacunas de assimilação identificadas na formação dos alunos, não possibilitando a acomodação dos conceitos que os pesquisadores acreditavam a priori terem sido assimilados.

[...] quando as relações substanciais ficam menos estabelecidas entre os conteúdos 
aprendidos e o novo e não há uma ligação com o que o aluno já conhece, então ocorre a aprendizagem memorística.

O jogo aplicado proporcionou aos alunos relembrar os conceitos que haviam estudado; entretanto, torna-se viável ressaltar que a função do jogo não é a memorização, mas sim que o aluno consiga relacionar e integrar o conhecimento que já tinha com as questões propostas pelo jogo. Devido às dificuldades por eles descritas com relação ao desconhecimento do conteúdo e ao próprio esquecimento, vale expor que o momento lúdico foi vivenciado pelos alunos, sendo importante atentar para como o ensino de química está envolvendo esses alunos, como eles estão e se estão realmente aprendendo os conteúdos propostos pelo currículo da disciplina (Passos, \& Ribeiro, 2012, p. 58).

Embora o trabalho de Passos e Ribeiro (2012) tenha objetivado a acomodação e atingido apenas o nível da assimilação, resultando em uma equilibração do tipo INTRA, observamos em um dos artigos que também utiliza o referencial explicitamente, a utilização de elementos da epistemologia Piagetiana que culminaram na acomodação, convergindo em uma equilibração INTER, que consiste na busca de associação entre os esquemas de assimilação que o sujeito possui, visando à acomodação do(s) conceito(s).

O artigo de Cavalcanti e Soares (2009) propõe um jogo de RPG como estratégia de discussão e avaliação de conceitos químicos. Na proposta desenvolvida pelos autores, há uma busca pela verificação do que os alunos possuem em sua estrutura cognitiva, de forma a identificar se os conceitos químicos estão acomodados, bem como a existência de possíveis assimilações deformantes, que poderiam acarretar na dificuldade de relacionar um esquema com o outro. Neste sentido, ao identificar erros conceituais, os jogadores juntamente com os pesquisadores discutiam tais questões, em busca de saná-las.

Se um aluno por ventura se equivocasse na descrição da síntese automaticamente era corrigido pelo colega e isso geraria uma discussão sobre o erro e consequentemente o acerto.

Notamos uma dificuldade em relação ao uso da linguagem química e da simbologia própria o que preliminarmente pode ter relação com uma má compreensão do conhecimento, o que gerou uma assimilação errônea e até mesmo o conceito pode não ter sido assimilado pelos estudantes (Cavalcanti, \& Soares, 2009, p. 269-273).

Além das assimilações deformantes, identificou-se que os alunos apresentavam dificuldade em relação à resolução de algumas atividades, pelo fato delas necessitarem de uma relação entre os esquemas já assimilados pelos jogadores. Essa dificuldade foi justificada por Mortimer, Machado e Romanelli (2000) citado por Cavalcanti e Soares (2009, p. 272),

[...] a quantidade de conceitos ou definições e procedimentos que são introduzidos na sala de aula é muito grande para que seja possível o aluno em tão pouco tempo compreendêlos e liga-los em uma estrutura mais ampla que dê significado a aprendizagem da química. Aos alunos fica a impressão de se tratar de uma ciência totalmente desvinculada da realidade, que requer mais memória do que o estabelecimento de relações. 
O jogo mostrou-se uma ferramenta importante para possibilitar a inter-relação entre os esquemas já assimilados, pois os alunos estavam à vontade para expor suas ideias, e consequentemente poderiam através da atividade acomodar as informações que estavam apenas assimiladas ou assimiladas de forma errada, além da possibilidade de novas assimilações.

Em alguns casos, para a resolução de alguns enigmas, se fazia necessário, além de um conceito prévio, outro conceito que se relacionava diretamente com o primeiro, como por exemplo, o enigma do cilindro que os jogadores tomando de seus conhecimentos precisam resolver a questão do preenchimento do polígono dentro do cilindro. Os jogadores voluntários demoraram muito a descobrir tal relação, podendo-se inferir daí que o aprendizado é mesmo fragmentado e sem conexões.

Nota-se também que o RPG como ferramenta pedagógica faz com que o aluno discuta amplamente o conceito químico durante o jogo. O conceito que muitas vezes não está claro para o aluno, começa a ter um certo significado, quando este o discute com os outros jogadores, além das várias intervenções do mestre, aprofundando as discussões levando o aluno a um melhor aproveitamento do conceito e consequente compreensão do mesmo (Cavalcanti, \& Soares, 2009, p. 273-280).

Assim, o artigo de Cavalcanti e Soares (2009) foi o único que atingiu a equilibração INTER (Figura 6), evidenciando dentre os demais o conhecimento dos pesquisadores acerca da Teoria da Equilibração de Jean Piaget, que convergiu em uma proposta lúdica que culminou em uma melhoria na aprendizagem por parte dos alunos.

\begin{tabular}{|l|c|c|c|c|c|}
\hline \multicolumn{1}{|c|}{ Artigos } & Implícito & Explícito & $\begin{array}{c}\text { Equilibração } \\
\text { INTRA }\end{array}$ & $\begin{array}{c}\text { Equilibração } \\
\text { INTER }\end{array}$ & $\begin{array}{c}\text { Equilibração } \\
\text { TRANS }\end{array}$ \\
\hline Benedetti Filho et al. & $\mathrm{X}$ & & $\mathrm{X}$ & & \\
\hline Castro, Dionízio, \& Silva & $\mathrm{X}$ & & $\mathrm{X}$ & & \\
\hline Cavalcanti, \& Soares & & $\mathrm{X}$ & & $\mathrm{X}$ & \\
\hline Ferreira, \& Nascimento & $\mathrm{X}$ & & $\mathrm{X}$ & & \\
\hline Giacomini et al. & & $\mathrm{X}$ & $\mathrm{X}$ & & \\
\hline Oliveira, \& Soares & & $\mathrm{X}$ & $\mathrm{X}$ & & \\
\hline Passos, \& Ribeiro & & $\mathrm{X}$ & $\mathrm{X}$ & & \\
\hline Rodríguez & $\mathrm{X}$ & & $\mathrm{X}$ & & \\
\hline Roque & $\mathrm{X}$ & & $\mathrm{X}$ & & \\
\hline Santos et al. & $\mathrm{X}$ & & $\mathrm{X}$ & & \\
\hline $\begin{array}{l}\text { Saturnino, Luduvico, \& } \\
\text { Santos }\end{array}$ & & $\mathrm{X}$ & $\mathrm{X}$ & & \\
\hline Tasca, Tubino, \& Simoni & $\mathrm{X}$ & & $\mathrm{X}$ & & \\
\hline Vaz, \& Soares & $\mathrm{X}$ & & $\mathrm{X}$ & & \\
\hline
\end{tabular}

Figura 6. Classificação dos artigos em relação à utilização do referencial epistemológico e o nível de equilibração atingido.

Fonte: Autores. 
Sendo assim, a análise dos jogos que utilizaram as concepções Piagetianas ressaltou a necessidade de um aprofundamento teórico/epistemológico, pois embora diversos pesquisadores do jogo ressaltem suas potencialidades enquanto ferramenta de ensino observou-se que o conhecimento do referencial epistemológico é importante no sentido de possibilitar que o jogo de fato apresente possibilidades reais de aprendizagem, e não seja simplesmente uma ferramenta de comprovação de conceitos trabalhados em aulas expositivas, visto que um único artigo atingiu a uma possível equilibração em termos de aprendizagem nos alunos, que consiste na inter-relação entre os esquemas de assimilação (acomodação).

\section{Jogando com Vigotski}

A partir da compreensão do jogo na concepção Vigotskiana, identificou-se um quantitativo de artigos menor, 29,17\%, que corresponde a sete (Figura 7) dos vinte e quatro trabalhos analisados.

\begin{tabular}{|l|l|l|}
\hline Autor(es) & Título do trabalho & Ano \\
\hline Costa, \& Miranda & $\begin{array}{l}\text { Uma Atividade Lúdica com Aplicação do Jogo Lince para o Ensino } \\
\text { de Química: reconhecimento das vidrarias presentes no laboratório }\end{array}$ & 2016 \\
\hline Focetola et al. & $\begin{array}{l}\text { Os Jogos Educacionais de Cartas como Estratégia de Ensino em } \\
\text { Química }\end{array}$ & 2012 \\
\hline $\begin{array}{l}\text { Godoi, Oliveira, \& } \\
\text { Codognoto }\end{array}$ & $\begin{array}{l}\text { Tabela Periódica - Um Super Trunfo para Alunos do Ensino } \\
\text { Fundamental e Médio }\end{array}$ & 2010 \\
\hline Leite \& Rotta & $\begin{array}{l}\text { Digerindo a Química Biologicamente: A Ressignificação de } \\
\text { Conteúdos a Partir de Um Jogo }\end{array}$ & 2016 \\
\hline $\begin{array}{l}\text { Messeder, Neto, } \\
\text { Pinheiro, \& Roque }\end{array}$ & $\begin{array}{l}\text { Improvisações Teatrais no Ensino de Química: Interface entre Teatro } \\
\text { e Ciência na Sala de Aula }\end{array}$ & 2013 \\
\hline $\begin{array}{l}\text { Oliveira, Soares, \& } \\
\text { Vaz }\end{array}$ & $\begin{array}{l}\text { Banco Químico: um Jogo de Tabuleiro, Cartas, Dados, Compras e } \\
\text { Vendas para o Ensino do Conceito de Soluções }\end{array}$ & 2015 \\
\hline $\begin{array}{l}\text { Silva, Cordeiro \& } \\
\text { Kiill }\end{array}$ & $\begin{array}{l}\text { Jogo Didático Investigativo: Uma Ferramenta para o Ensino de } \\
\text { Química Inorgânica }\end{array}$ & 2015 \\
\hline
\end{tabular}

Figura 7. Artigos presentes na categoria Jogo na Concepção Vigotskiana

Fonte: Autores.

A análise dos jogos na concepção Vigotskiana permitiu-nos identificar a predominância de jogos de regras, sendo-as exploradas em todos os artigos; regras que são consideradas por Vigotski uma característica dos jogos. Análogo às regras, o artigo de Messeder Neto, Pinheiro e Roque (2013) utiliza as representações, para avaliar a concepção dos alunos acerca de conceitos Químicos.

As improvisações teatrais foram inicialmente utilizadas para o levantamento de concepções prévias dos alunos sobre o tema e, depois da mediação didática, as improvisações foram refeitas, buscando verificar se os conceitos discutidos foram incorporados pelos alunos (Messeder Neto, Pinheiro, \& Roque, 2013, p. 104). 
De acordo com Vigotski os jogos de representação/protagonizados são importantes no sentido de proporcionar uma forma das crianças se adentrarem no mundo dos adultos, diferentemente do que alguns autores consideram como uma fuga da realidade. A seguir apresentaremos algumas citações referentes à fala dos alunos acerca da proposta desenvolvida pelos pesquisadores, no sentido de confirmar a importância da representação para identificação do nível de desenvolvimento real dos alunos.

A4: "Mudou a forma de dar aula, gostei da criatividade de, em pouco tempo, conseguir fazer uma peça."

A5: "Foi ótimo, eu gostei de ver os outros apresentando. É importante ser plateia."

A6: "Eu achei interessante porque nós aprendeu a se comunicar através de gestos e mais importante sempre estava falando de química."

A7: "Eu gostei de me apresentar por que eu aprendi a não ter vergonha." (Messeder Neto, Pinheiro, \& Roque, 2013, p. 105).

Os níveis de desenvolvimento foram muito explorados nos artigos que utilizaram o referencial Vigotskiano, principalmente no que se refere à Zona de Desenvolvimento Proximal (Iminente), visto que constantemente os pesquisadores exploravam nos jogos uma oportunidade de favorecer o desenvolvimento por parte dos estudantes. De acordo com os autores dos trabalhos, através do contato com um ser mais desenvolvido, que poderia ser tanto o professor quanto os próprios colegas, os estudantes poderiam atingir certo nível de desenvolvimento que os possibilitasse transitar da Zona de Desenvolvimento Iminente para o Real, ou seja, apropriar-se de conceitos de forma a conseguir resolver as atividades sem o auxílio de um ser mais desenvolvido.

[...] o jogo demonstrou sua capacidade de trabalhar a intelectualidade do aluno dentro de sua Zona de Desenvolvimento Proximal (ZDP), tal como postulado por Vygotsky (2010) (Focetola et al., 2012, p. 254).

A escolha da situação-problema a ser encenada também requer cuidado especial ao ser selecionada pelo professor, pois é por meio dela que o estudante poderá mostrar se aprendeu o conhecimento transmitido na sala. A situação problema deve ser desafiadora, mas deve estar dentro da zona de desenvolvimento proximal (ZDP) do aluno. [...] Em termos vygotskyanos, podemos dizer que é necessário conhecer o nível de desenvolvimento atual do estudante para, desse modo, atuarmos na ZDP e os levarmos a desenvolver novos conhecimentos químicos (Messeder Neto, Pinheiro, \& Roque, 2013, p. 102-105).

Contudo, percebe-se através da citação que os pesquisadores apropriaram-se de termos que não são mais utilizados, pois são decorrentes de traduções norte-americanas da obra Vigotskiana, que convergiu em diversos equívocos de tradução no que se refere à interpretação do desenvolvimento na concepção de Vigotski, devido à utilização de três termos para retratar o desenvolvimento, tais como: desenvolvimento real, potencial 
e proximal.

A característica central que se destaca na teoria de Vygotsky, e que é muito utilizada pela pedagogia, é a chamada ZDP, definida como: [...] a distância entre o nível de desenvolvimento determinado pela capacidade de resolver um problema e o nível de desenvolvimento potencial determinado através da solução de um problema sob a ajuda de um adulto ou em colaboração com outro colega mais capaz (Vygotsky, 2007, p. 97 citado por Messeder Neto, Pinheiro \& Roque, 2013, p. 103).

Ao utilizar tais traduções, os pesquisadores não se atentam à instrução como uma atividade que pode ou não levar ao desenvolvimento. "Vigotski não diz que a instrução é garantia de desenvolvimento, mas que ela, ao ser realizada em uma ação colaborativa, seja do adulto ou entre pares, cria possibilidades para o desenvolvimento" (Prestes, 2012, p. 190).

$\mathrm{Na}$ concepção Vigotskiana zona blijaichego razvitia (traduzida em alguns livros como Zona de Desenvolvimento Proximal) está relacionado com o que a criança consegue realizar com a ajuda do adulto, e não se limita a situações escolares, diferentemente do entendimento de algumas traduções como: "A formação social da mente (2007)" da editora Martins Fontes, que reduz a teoria às relações professor x aluno, e equivocadamente a interpreta como o momento em que os estudantes conseguem resolver seus problemas sem a mediação do professor, sendo que para Vigotski, o que a criança realiza sem a ajuda do adulto caracteriza-se como nível de desenvolvimento atual ou real, que além de revelar as funções amadurecidas, identificam as funções que estão amadurecendo (Prestes, 2012).

Nesse sentido, tanto para Duarte (2001) quanto para Prestes (2012), não faz sentido utilizar três termos para explicar o desenvolvimento, pois para Vigotski existe aquilo que o indivíduo faz sozinho, que consiste no desenvolvimento atual ou real, e o que ele faz com ajuda de um ser mais desenvolvido, que é denominado desenvolvimento próximo ou iminente. Logo, não faz sentido mensurar uma zona transição entre os dois tipos de desenvolvimento, pois o que o indivíduo faz hoje em colaboração, com o auxílio de um ser mais desenvolvido, ele fará amanhã sozinho.

Assim como a predominância das regras, percebeu-se que os pesquisadores exploram nos jogos as interações sociais, no qual o ser mais desenvolvido poderia auxiliar seus pares na realização das atividades, além de possibilitar o desenvolvimento das Funções Psicológicas Superiores (FPS) dos alunos.

Aluno A: "No jogo, eu aprendi mais com o colega, porque com os colegas eu pude interagir".

Aluno B: "Com o jogo, eu aprendi com os colegas e a pesquisadora, eu conversei muito com eles e tirei minhas dúvidas".

Aluno C: "Quando estava jogando, eu aprendi muito mais com a pesquisadora, porque ela nos explicou muito bem sobre os casos". 
Aluno D: "No jogo, eu aprendi com os colegas e a pesquisadora, pois eles auxiliavam em minhas dúvidas" (Silva, Cordeiro, \& Kiill, 2015, p. 32).

As citações extraídas do artigo de Silva, Cordeiro e Kiill (2015) evidenciam a importância dada por Vigotski citado por Messeder Neto (2016) às relações sociais, que são importantes no sentido de inserir os jogadores em uma determinada cultura. Desta forma, os integrantes do jogo se solidarizam e compartilham suas concepções de mundo, que convergem para o desenvolvimento de suas FPS.

De acordo com Messeder Neto (2016), as FPS são construídas a partir do aprendizado social, que influencia significativamente no desenvolvimento dos indivíduos. Essas funções são mediadas por signos, que no caso das atividades mencionadas se organizam a partir dos jogos, sendo estes os meios utilizados para realização de tarefas psicológicas, no qual o sujeito utiliza-os para controlar sua própria conduta, enquanto as funções elementares são reguladas pelo ambiente.

[...] se por um lado nenhum processo é em si puramente elementar, porque a criança já nasce imersa na cultura, por outro lado o seu desenvolvimento pleno como FPS só acontecerá se ela se apropriar do legado cultural da humanidade. Quanto mais complexa e mais rica for essa apropriação, maior a chance de atingirmos as máximas potencialidades dessas FPS (Messeder Neto, 2016, p. 61).

As regras e as relações sociais exploradas pelos autores dos artigos são fundamentais no sentido de construir propostas lúdicas que sejam capazes de mostrar aos alunos a importância do trabalho em grupo, mas também para evidenciar os limites pelos quais eles podem percorrer, visto que assim como explicitado em um dos artigos, o jogo na concepção Vigotskiana surge em decorrência ou como forma de preparação para o trabalho, que nos impõe uma série de regras e requer relações sociais.

Huizinga (2007) destaca a grande importância dos jogos, além de simplesmente discutir conhecimentos. Segundo o autor, é por meio do jogo “[...] que a sociedade exprime sua interpretação da vida e do mundo [...]” (p. 75). O jogo na sala de aula não é exclusivamente para debater os conhecimentos, mas sim também para definir a cultura de cada ser. É pelo jogo que os membros de uma sociedade se formam e que a cultura de uma sociedade se solidifica. Ainda segundo Huizinga (2007), os jogos de infância vão dando lugar ao trabalho - que não deixará de ser um jogo, porém em um nível diferente de divertimento/ludicidade (Oliveira, Soares, \& Vaz, 2015, p. 286).

Embora os jogos que utilizam a concepção Vigotskiana explorem aspectos que fazem parte da Psicologia Histórico Cultural, percebeu-se que os pesquisadores ficam reféns da utilização do jogo como uma forma de proporcionar autonomia aos alunos, pois na maioria dos casos, os autores buscam incessantemente seu desenvolvimento, para que eles possam realizar atividades sem o auxílio dos professores.

\section{O Jogo pelo Jogo}

Dentre os artigos analisados, quatro foram elencados na categoria Ausência de Referencial Epistemológico (Figura 8), por não utilizarem nenhum referencial 
epistemológico.

\begin{tabular}{|l|l|l|}
\hline Autor(es) & Título do trabalho & Ano \\
\hline $\begin{array}{l}\text { Olivares, Costa \& } \\
\text { Queiroz }\end{array}$ & $\begin{array}{l}\text { Jogos de Empresa: aplicação à gestão da qualidade no Ensino } \\
\text { Superior de Química }\end{array}$ & 2011 \\
\hline Santos, \& Michel & Vamos jogar uma SueQuímica? & 2009 \\
\hline Soares, \& Cavalheiro & O ludo como um jogo para discutir conceitos em Termoquímica & 2006 \\
\hline $\begin{array}{l}\text { Soares, Okumura, \& } \\
\text { Cavalheiro }\end{array}$ & $\begin{array}{l}\text { Proposta de um Jogo Didático para ensino do conceito de } \\
\text { Equilíbrio Químico }\end{array}$ & 2003 \\
\hline
\end{tabular}

Figura 8. Artigos presentes na categoria Ausência de Referencial Epistemológico

Fonte: Autores.

Assim como os trabalhos categorizados como Vigotskianos e Piagetianos, os jogos que não utilizaram nenhum referencial epistemológico são também jogos de regras, contudo, verificou-se uma peculiaridade nos trabalhos elencados nessa categoria, pois os autores exploram nas regras dos jogos, uma maneira de preparar os estudantes para o mercado de trabalho, por meio de treinamento, que de acordo com os referenciais epistemológicos elencados na pesquisa, não contribui para a aprendizagem dos estudantes.

Os jogos de empresa apareceram há muito tempo, sendo destinados à avaliação de táticas e estratégias em campo de batalha frente a um inimigo real (jogos de guerra). Em 1956, um grupo de pesquisadores da American Management Association (AMA) proporcionou a adaptação da filosofia e dos procedimentos adotados nos jogos de guerra para o ambiente empresarial, tendo lançado o Top Management Decision Game - uma ferramenta para treinamento de executivos, muito elementar (Olivares, Costa, \& Queiroz, 2011, p. 1812).

A análise dos trabalhos presentes na referida categoria evidencia que os autores provavelmente desconhecem as possibilidades dos jogos e atividades lúdicas enquanto metodologias de ensino e aprendizagem, visto que em todos os artigos há apenas a descrição das etapas desenvolvidas, sem nenhuma discussão teórica acerca dos resultados obtidos, que possa remeter à aprendizagem dos estudantes. Estes trabalhos associam o lúdico somente a momentos de diversão, desconsiderando todas as suas possibilidades pedagógicas, fato que converge com diversas situações presenciadas na área de Educação em Ciências, dos quais pesquisadores de áreas distintas têm utilizado discursos reducionistas que descaracterizam o jogo enquanto metodologia de ensino.

Assim como o bom desempenho, uma receptividade favorável à proposta de ensino por parte dos alunos era aguardada como indicativo do sucesso da atividade. [...] Além da boa receptividade da atividade é importante destacar que os alunos tiveram grande dedicação ao seu cumprimento, o que leva ao bom desempenho e resulta em boas notas (Olivares, Costa, \& Queiroz, 2011, p. 1815-1816).

Estas questões vêm sendo evidenciadas em eventos científicos e também 
em pareceres de periódicos científicos renomados, dos quais pesquisadores que possivelmente desconhecem o objeto de estudo, aprovam trabalhos que não apresentam nenhuma consistência teórica e/ou contribuição científica, pois trazem apenas descrições superficiais de jogos, tecemos uma crítica também na direção oposta, pois têm-se identificado trabalhados que apresentam uma consistência teórica boa, com resultados relevantes para a área, que simplesmente são recusados, sem sequer terem oportunidade de realizar as alterações que os pareceristas julgassem necessário.

A análise dos artigos na referida categoria, evidencia a necessidade de se discutir o papel do jogo no sistema educacional, pois a forma com que tais artigos são organizados reduzem os jogos a propostas meramente interativas (lúdicas), que desconsideram sua função educativa. Assim, ressaltamos a importância de se fortalecer a área por meio de debates, discussões e disseminação das pesquisas que vêm sendo realizadas e tem obtido bons resultados no que se refere à utilização do lúdico como metodologia de ensino, que favorece a aprendizagem dos alunos. A quantidade de trabalhos classificados na categoria em questão aponta para a necessidade de um aprofundamento teórico/epistemológico, no sentido de desconstruir tais discursos, da utilização do lúdico como uma brincadeira e/ou forma de romper com a rotina de aulas expositivas.

Finalmente, entendemos que nossa análise foi mais efetiva e completa dentro da perspectiva Piagetiana, pois os artigos analisados apresentaram mais elementos dessa teoria. Quando consideramos a perspectiva Vigotskiana e também a ausência de referencial, constatamos certa superficialidade nestes vieses, não permitindo uma análise mais ampla.

\section{Considerações Finais}

A partir da análise dos jogos utilizados no Ensino de Química no século XXI (período de 2000-2016), percebeu-se que independentemente do referencial epistemológico adotado ou ausência dele, todos os jogos são jogos de regras, sendo que em muitos casos evidenciou-se a individualidade da produção do conhecimento, na contramão do que propõe os teóricos analisados, que ressaltam a importância das relações sociais para o desenvolvimento.

Nesse cenário de individualidade, torna-se cada vez mais necessário o desenvolvimento de propostas de ensino que busquem a construção do conhecimento científico de forma coletiva, e neste âmbito, os jogos podem ser uma alternativa eficaz, desde que considerados pelos pesquisadores e futuros professores que a construção do conhecimento é realizada de forma coletiva, apresentando aos alunos uma série de desafios, que são desenvolvidos de forma coletiva e a solução do caso se dá por meio do compartilhamento das informações obtidas por todos os participantes, ou seja, não há um único vencedor.

A análise dos jogos aponta também para uma necessidade de se discutir o papel do jogo enquanto metodologia de ensino e aprendizagem, pois a utilização de referenciais epistemológicos ainda é muito incipiente, sendo que poucos conceitos 
teóricos são explorados pelos pesquisadores. Desta forma, os jogos praticamente não levam em consideração o ensino (pois são propostas que têm objetivado confirmar os conceitos trabalhos em aulas expositivas) e pouco tem favorecido a aprendizagem dos alunos.

Os resultados obtidos tanto na categoria Piagetiana quanto na Vigotskiana, indicam que a maioria dos jogos utilizam os referenciais epistemológicos como metodologia de aprendizagem, pois tais concepções são elencadas com objetivo de confirmar os conceitos trabalhados nas aulas expositivas, o que não tem contribuído para a aprendizagem dos alunos, pois mesmo que as propostas objetivem as relações sociais entre os discentes, elas evidenciam o desconhecimento dos alunos acerca dos conceitos que deveriam ter sido aprendidos por meio dos métodos expositivos.

Desta forma, para que os jogos apresentem resultados mais significativos, é necessário não apenas o conhecimento dos pesquisadores acerca do referencial que estão adotando, mas também uma mudança metodológica no sistema educacional, pois diante aos resultados, fica evidente que mesmo que os jogos objetivem a inter-relação entre o conhecimento que os alunos deveriam ter assimilados (como foi o caso dos três artigos Piagetianos que buscaram a acomodação), a aprendizagem não é favorecida, pois os métodos de ensino atuais tem contribuído para uma aprendizagem memorística, cujas informações tem sido decoradas e posteriormente esquecidas pelos estudantes.

Em relação às pesquisas na área do lúdico, importante salientar que a simples utilização de jogos e atividades lúdicas sem nenhum conhecimento teórico/ epistemológico, em nada contribui para os processos de ensino e aprendizagem, e mesmo que os jogos estejam em evidência, é indispensável que os pesquisadores tenham um compromisso pedagógico, e não utilizem essa metodologia de ensino apenas para romper com a rotina de aulas expositivas e dialogadas.

Neste sentido, o presente trabalho aponta que o jogo aliado a um referencial epistemológico pode ser considerado uma importante metodologia de ensino, mas para que ele também favoreça a aprendizagem dos estudantes, é necessário que os autores se apropriem dos referenciais adotados, de forma a possibilitar mudanças efetivas nas atuais conjunturas do sistema educacional, no sentido de viabilizar uma educação que se distancie da memorização.

\section{Referências}

Aguiar Jr., O. (1999). As três formas da equilibração: análise do material didático de um curso de eletricidade básica. Caderno Catarinense de Ensino de Física, 16(1), 72-91.

Benedetti Filho, E., Fiorucci, A. R., Benedetti, L. P. S., \& Craveiro, J. A. (2009). Palavras cruzadas como recurso didático no ensino de teoria atômica. Química Nova na Escola, 31(2), 88-95. 
Castro, D. L. de, Dionízio, T. P., \& Silva, I. G. (2015). Na trilha dos Elementos Químicos: o Ensino de Química através de uma atividade lúdica. Revista Brasileira de Ensino de Química. 10(1), 46-58.

Cavalcanti, E. L. D., \& Soares, M. H. F. B. (2009). O uso do jogo de roles (roleplaying game) como estratégia de discussão e avaliação do conhecimento químico. Revista Electrónica de Enseñanza de las Ciencias, 8(1), 255-282.

Cleophas, M. das G., Cavalcanti, E. L. D., \& Soares, M. H. F. B. (2018). Afinal de contas, é jogo educativo, didático ou pedagógico no ensino de Química/Ciências? Colocando os pingos nos “is”. In M. das G., Cleophas, \& M. H. F. B. Soares (Org.), Didatização Lúdica no Ensino de Química/Ciências (pp. 33-62). São Paulo, SP: Livraria da Física.

Costa, M. A., \& Miranda, A. L. N. (2016). Uma atividade lúdica com aplicação do jogo Lince para o Ensino de Química: reconhecimento das vidrarias presentes no laboratório. Revista Brasileira de Ensino de Química, 11(1), 68-73.

Duflo, C. (1999). O jogo: de Pascal a Schiller. Porto Alegre: Artes Médicas.

Elkonin, D. B. (2009). Psicologia do jogo. São Paulo: Martins Fontes.

Ferreira, V. R. F. (2016). O Movimento Escoteiro e a Educação não formal no ensino e aprendizagem de conceitos químicos. Dissertação (Mestrado em Educação em Ciências e Matemática). Universidade Federal de Goiás, Goiânia.

Ferreira, W. M., \& Nascimento, S. P. F. (2014). Utilização do jogo de tabuleiro - ludo no processo de avaliação da aprendizagem de alunos surdos. Química Nova na Escola, $36(1), 28-36$.

Flick, I. (2009). Introdução à pesquisa qualitativa. Porto Alegre: Artmed.

Focetola, P. B. M., Castro, P. J., Souza, A. C. J., Grion, L. S., Pedro, N. C. S., Iack, R. S., Almeida, R. X., Oliveira, A. C., Barros, C. V. T., Vaitsman, E., Brandão, J. B., Guerra, A. C. O., \& Silva, J. F. M. (2012). Os Jogos Educacionais de Cartas como Estratégia de Ensino em Química. Química Nova na Escola, 34(4), 248-255.

Garcez, E. S. C. (2014). O Lúdico em Ensino de Química: um estudo estado da arte. Dissertação (Mestrado em Educação em Ciências e Matemática), Universidade Federal de Goiás, Goiânia.

Gerhardt, T. E., \& Silveira, D. T. (2009). Métodos de Pesquisa. Porto Alegre: Editora da UFRGS.

Giacomini, R. A., Miranda, P. C. M. L., Silva, A. S. K. P., \& Ligiero, C. B. P. (2006). Jogo Educativo Sobre a Tabela Periódica Aplicado no Ensino de Química. Revista Brasileira de Ensino de Química, 1(1), 61-76.

Godoi, T. A. F., Oliveira, H. P. M., \& Codognoto, L. (2010). Tabela Periódica - Um Super Trunfo para Alunos do Ensino Fundamental e Médio. Química Nova na Escola, 32(1), 22-25. 
Groos, K. (1902). Le jeu des animaux. Paris: Paris.

Kishimoto, T. M. (2011a). Jogo, brinquedo, brincadeira e a educação. 14. ed. São Paulo: Editora Cortez.

Kishimoto, T. M. (2011b). O brincar e suas teorias. São Paulo: Editora Cengage Learning.

Leite, L. M., \& Rotta, J. C. G. Digerindo a Química Biologicamente: a ressignificação de conteúdos a partir de um jogo. Química Nova na Escola, 38(1), 12-19.

Lüdke, M., \& André, M. E. D. A. (1986). Pesquisa em Educação: Abordagens Qualitativas. São Paulo: EPU.

Messeder Neto, H. S., Pinheiro, B. C. S., \& Roque, N. F. (2013). Improvisações Teatrais no Ensino de Química: Interface entre Teatro e Ciência na Sala de Aula. Química Nova na Escola, 35(2), 100-106.

Messeder Neto, H. S. (2016). O lúdico no ensino de Química na Perspectiva HistóricoCultural: além do espetáculo, além da aparência. Curitiba: Editora Prismas.

Olivares, I. R. B., Costa, D. L. L. B., \& Queiroz, S. L. (2011). Jogos de Empresa: aplicação à gestão da qualidade no Ensino Superior de Química. Química Nova, 34(10), 1811-1817.

Oliveira, J. S., Soares, M. H. F. B., \& Vaz, W. F. (2015). Banco Químico: um Jogo de Tabuleiro, Cartas, Dados, Compras e Vendas para o Ensino do Conceito de Soluções. Química Nova na Escola, 37(4), 285-293.

Oliveira, A. S., \& Soares, M. H. F. B. (2005). Júri Químico: uma atividade lúdica para discutir conceitos Químicos. Química Nova na Escola, 21, 18-24.

Passos, I. N. M., \& Ribeiro, K. D. F. (2012). Quest Química: um jogo como ferramenta na abordagem e aprimoramento do conhecimento químico. Revista Brasileira de Ensino de Química, 7(2), 47-60.

Piaget, J. (1978). A formação do símbolo na criança: imitação, jogo e sonho, imagem e representação. 3. ed. Rio de Janeiro: Zahar Editores.

Piaget, J. (2014). Relações entre a Afetividade e a Inteligência no Desenvolvimento Mental da Criança. Rio de Janeiro: Wak Editora.

Porto, M. G. C. (2015). Jogo, TIC e ensino de química: Uma proposta pedagógica. 2015. Tese (Doutorado em Educação em Ciências e Matemática). Universidade Federal Rural de Pernambuco, Recife.

Rezende, F. A. de M. (2017). Jogos no ensino de Química: um estudo sobre a presença/ ausência de teorias de ensino e aprendizagem à luz do $V$ Epistemológico de Gowin. Dissertação (Mestrado em Educação em Ciências e Matemática). Universidade Federal de Goiás, Goiânia. 
Rodríguez, F. P. (2007). Competencias comunicativas, aprendizaje y enseñanza de las Ciencias Naturales: un enfoque lúdico. Revista Electrónica de Enseñanza de las Ciencias. 6(2), 275-298.

Roque, N. F. (2007). Química por meio do teatro. Química Nova na Escola, 25, 27-29.

Santos, A. P. B., \& Michel, R. C. (2009). Vamos jogar uma SueQuímica? Química Nova na Escola, 31(3), 179-183.

Santos, J. S., Silva, D. M., Silva, A. F. C., Oliveira, J. J. S., \& Silva, A. B. (2012). Aplicação de um Jogo Didático (Ludo) Explorando o Conteúdo da Tabela Periódica no Ensino Médio. Revista Brasileira de Ensino de Química, 7(2), 61-68.

Saturnino, J. C. S. F., Luduvico, I., \& Santos, L. J. (2013). Pôquer dos Elementos dos Blocos s e p. Química Nova na Escola, 35(3), 174-181.

Silva, B., Cordeiro, M. R., \& Kiill, K. B. (2015). Jogo Didático Investigativo: Uma Ferramenta para o Ensino de Química Inorgânica. Química Nova na Escola, 37(1), 2734.

Soares, M. H. F. B. (2015). Jogos e Atividades Lúdicas para o Ensino de Química. 2. ed. Goiânia: Kelps.

Soares, M. H. F. B., \& Cavalheiro, E. T. G. (2006). O ludo como um jogo para discutir conceitos em Termoquímica. Química Nova na Escola, 23, 27-31.

Tasca, R. A., Tubino, M., \& Simoni, J. de A. (2007). Dois jogos que auxiliam no entendimento da Tabela Periódica. Revista Brasileira de Ensino de Química. 2(1), 69-75.

Triviños, A. N. S. (1987). Introdução à pesquisa em Ciências Sociais: a pesquisa qualitativa em educação. São Paulo: Atlas.

Vaz, W. F., \& Soares, M. H. F. B. (2008). O ensino de Química para adolescentes em conflito com a lei: possibilidades e desafios. Revista Brasileira de Pesquisa em Educação em Ciências. 8(3), 123.

Vigotski, L. S. (2007). A brincadeira e o seu papel no desenvolvimento psíquico da criança. Revista de Gestão de Iniciativas Sociais, Rio de Janeiro, 11, 23-36. 
Felipe Augusto de Mello Rezende

${ }^{1}$ https://orcid.org/0000-0003-1390-3658

Universidade Federal de Goiás Instituto de Química Goiânia, Goiás, Brasil felipemelloquimica@hotmail.com

Márlon Herbert Flora Barbosa Soares

${ }^{\oplus}$ https://orcid.org/0000-0002-3273-8603 Universidade Federal de Goiás Instituto de Química Goiânia, Goiás, Brasil marlon@ufg.br

Submetido em 28 de março de 2019 Aceito em 17 de outubro de 2019 Publicado em 12 de dezembro de 2019 